support this suggestion. In three cases enzyme changes alone were considered insufficient evidence for further infarction. Electrical instability of the heart as a definite cause of late ventricular dysrhythmias can only be incriminated with certainty in patients in whom an irritable myocardium persists after the acute phase. Denborough et al. (1968) postulated an increased sensitivity to catecholamines as a cause of late ventricular dysrhythmias. Bjerkelund (1957) suggested that a sudden disturbance of electrical conduction of the heart might lead to ventricular fibrillation or asystole. Various other precipitating factors have also been implicated, including inadequate rest, acidosis, hypoxia, excessive diuresis leading to hypokalaemia, digitalis therapy, and anaesthetic agents (Robinson et al., 1964 ; Restieaux et al., 1967 ; Siddons and Sowton, 1967). Oliver et al. (1968) showed a relationship between the level of free fatty acids in the serum and the incidence of early and late ventricular dysrhythmias. These authors, however, are undecided whether this relationship results from increased catecholamine activity or whether it is directly due to an increase in myocardial oxygen consumption caused by the utilization of free fatty acids.

Late ventricular dysrhythmias after myocardial infarction are particularly apt to occur in patients whose initial course is complicated by left ventricular failure, hypotension, or dysrhythmias. These late dysrhythmias are usually not heralded by a further episode of cardiac pain. Such "high risk" patients should be transferred to a ward adjacent to the coronary care unit before being moved to a more remote general ward. There is no evidence that anticoagulant drugs at present in use can reduce the incidence of further coronary occlusion or of late sudden death after myocardial infarction (Bjerkelund, 1957 ; Aspenström and Korsan-Bengsten, 1964 ; Denborough et al., 1968).

If the finding of further infarction or of fresh coronary occlusion in our small series is significant, there should then be a definite indication for the use of an effective antithrombotic agent in these patients. Electrical instability of the type that might benefit from prolonged use of antiarrhythmic agents is suggested by recurrent ventricular tachycardia or fibrillation in the acute phase of the infarction, or by the occurrence of multiple ventricular ectopic beats, especially of the $R$ on $T$ type
(Smirk and Palmer, 1960). Increasing sinus bradycardia, complete heart block, and a previous cardiac arrest are warnings of possible asystole, usually unsalvable (Meltzer and Kitchell, 1966 ; Lawrie et al., 1967). The patients for whom one has obviously the greatest responsibility are those with hearts that are "too good to die" (Beck and Leighninger, 1960). This has been shown in our small series to be a factor as worthy of attention in late cardiac arrests as in the early ones.

\section{REFERENCES}

Antonis, A. (1965). F. Lipid Res., 6, 307.

Aspenström, G., and Korsan-Bengsten, K. (1964). Acta med. scand., 176, 563.

eck, C. S., and Leighninger, D. S. (1960). F. Amer. med. Ass., 174, 133.

Bjerkelund, C. J. (1957). Acta med. scand., Suppl. No. 330.

Day, H. W. (1965). Amer. F. Cardiol., 15, 51.

Day, H. W. (1968). Amer. F. Cardiol., 21, 252.

Denborough, M. A., Lovell, R. R. H., Nestel, P. J., and Goble, A. J. (1968). Lancet, 1, 386.

Geddes, J. S., Adgey, A. A. J., and Pantridge, J. F. (1967). Lancet, 2, 273. Goble, A. J., Sloman, G., and Robinson, J. S. (1966). Brit. med. F., 1,

Julian, D. G., Valentine, P. A., and Miller, G. G. (1964). Amer. F. Med., 37, 915.

Killip, T., and Kimball, J. T. (1967). Amer. F. Cardiol., 20, 457.

Lawrie, D M., et al. (1967). Lancet, 2, 109.

Lown, B., Vassaux, C., Hood, W. B., Fakhro, A. M., Kaplinsky, E., and Roberge, G. (1967). Amer. f. Cardiol., 20, 494 .

MacMillan, R. L., Brown, K. W. G., Peckham, G. B., Kahn, O., Hutchison, D. B., and Paton, M. (1967). Amer. F. Cardiol., 20, 451 . Meltzer, L. E., and Kitchell, J. B. (1966). Progr. cardiovasc. Dis., 9, 50. Oliver, M. F., Julian, D. G., and Donald, K. W. (1967). Amer. F. Cardiol., 20, 465.

Oliver, M. F., Kurien, V. A., and Greenwood, T. W. (1968). Lancet, 1, 710.

Pantridge, J. F., and Geddes, J. S. (1967). Lancet, 2, 271.
Pentecost, B. L., and Mayne, N. M. C. (1968). Brit. med. F., 1, 830.

Restieaux, N., et al. (1967). Lancet, 1, 1285.

Robinson, J, S., Sloman, G., and McRae, C. (1964). Med. F. Aust., 1, 427 .

Siddons, H., and Sowton, E. (1967). Cardiac Pacemakers. Springfield,

Illinois.

Spracklen, F. H. N., Kimerling, J. J., Besterman, E. M. M., and Litchfield, J. W. (1968). Brit. med. F., 1, 89.

Thomas, M., Jewitt, D. E., and Shillingford, J. P. (1968). Brit. med. F., 1, 787 .

Wolff, G. A., Veith, F., and Lown, B. (1968). Cardiovasc. Res., 2, 111.

Wolf, G. A., Veith, F., and Lown, B. (1968). Cardiovasc. Res., 2, 111.
Yu, P. N., Fox, S. M., Imboden, C. A., and Killip, T. (1965). Mod. Conc. cardiovasc. Dis., 34, 23.

\title{
Dipyridamole : a Controlled Trial of its Effect in Acute Myocardial Infarction
}

\author{
A. E. GENT,* M.B., M.R.C.P. ; C. G. D. BROOK,* $\neq$ M.B., M.R.C.P.; T. H. FOLEY, † M.B., B.SC., M.R.C.P. \\ T. N. MILLER, *§ B.M., M.R.C.P.
}

Brit. med. $7 ., 1968,4,366-368$

\begin{abstract}
Summary : A controlled trial of oral dipyridamole in 103 patients with acute myocardial infarction showed no difference in the number of complications or deaths in either the control or the treated groups. It is concluded that dipyridamole has no benefit in acute myocardial infarction.
\end{abstract}

\section{Introduction}

The pyrimidopyrimidine derivative, dipyridamole (Persantin), has been shown in animal experiments to inhibit thrombus

* Medical Registrar, St. Thomas's Hospital, London S.E.1.

t Lecturer in Medicine, St. Thomas's Hospital, London S.E.1.

$¥$ House-physician, Hospital for Sick Children, Great Ormond Street, London W.C.1.

$\checkmark$ Senior Medical Registrar, Westminster Hospital, London S.W.1. formation in injured vessels and to increase the collateral circulation around an ischaemic area in the myocardium (Fam and McGregor, 1964 ; Emmons et al., 1965a ; Rees and Redding, 1967). The drug has been the subject of a number of clinical trials to assess its effect in angina, but its effect in acute myocardial infarction has not been evaluated. It is the purpose of this trial to determine the influence of treatment with dipyridamole on mortality and complications in the four weeks following acute myocardial infarction.

\section{Patients and Miethods}

Patients admitted to the trial received dipyridamole or placebo tablets, and the selection was made at random. Eleven patients, six in the placebo group and five in the treatment 
group, all of whom survived, were treated initially in the intensive care ward, but the majority were admitted direct to a general medical ward. Treatment and observation continued for 28 days and the physicians responsible for the patients' management were not informed whether the patients were receiving active or placebo tablets.

Patients were admitted to the trial if they were thought to have had a myocardial infarct within two weeks before admission. The diagnosis of myocardial infarction was based on the generally accepted clinical criteria of history, physical signs, classical E.C.G. changes, and changes in serum transaminase levels. The grounds for exclusion from the trial were evidence of liver disease, the intention to treat with anticoagulants or such treatment during the previous two weeks, malignant hypertension, and a history of bleeding diathesis. No exclusion was made on the basis of age, sex, history of previous cerebrovascular accident, or of previous gastrointestinal bleeding.

The patients were assigned to treatment groups by means of a number issued by the pharmacy, and the bottle of tablets with the corresponding number was dispensed. In case of emergency it was possible to identify the tablets by means of a code kept in the pharmacy, and had this been necessary the patient would have been withdrawn from the trial. In fact, no patient had to be withdrawn for this reason. One tablet was given by mouth four times a day, and treatment was continued for four weeks from the time of entry to the trial and not from the time of onset of the infarction. Each tablet of dipyridamole contained $100 \mathrm{mg}$. The patient was not necessarily kept in hospital for the full 28 days of the trial. Cardiac failure, shock, and other complications of myocardial infarction were treated according to standard practice.

A standard 12-lead electrocardiogram was taken on admission and during the first week, and was repeated during the second and third weeks. The serum aspartate aminotransferase was estimated three times during the first five days. Blood for estimation of serum dipyridamole levels was taken when possible on the second and fifth days and then at weekly intervals. The dipyridamole levels were estimated in the department of the Regius Professor of Medicine at Oxford. The length of time spent in bed by each patient was recorded. If reinfarction was thought to have occurred E.C.G. and serum aspartate aminotransferase estimations were repeated as for the initial episode. The diagnosis of reinfarction was accepted if typical Q-wave, S-T segment, and T-wave changes appeared in E.C.G. leads previously not affected, or if serum aspartate aminotransferase levels showed a transient rise above 40 units. If after admission to the trial it became apparent that the original diagnosis was incorrect the patient was withdrawn, but observations were continued for the full 28 days.

The complications of myocardial infarction to which particular attention was paid were systemic and pulmonary emboli and leg vein thrombosis. If these were thought to have occurred then anticoagulants were given as necessary, and, indeed, the physician in charge of the case was free to prescribe anticoagulants at any time during the 28 days if he wished.

\section{Results}

The 120 patients admitted to the trial comprised 102 men and 18 women. Seventeen were withdrawn from the trial; in five the initial diagnosis was found to be incorrect and in a further five there was insufficient objective evidence to support the original diagnosis. In two cases the treatment was stopped by the physician in charge because the patients claimed that the tablets gave them chest pain. Both these patients were tense and introspective, but the tablets they were receiving were active. One man who suffered repeated attacks of ventricular fibrillation for which intravenous lignocaine was given had a persistant pyrexia of $107^{\circ} \mathrm{F} .\left(41.7^{\circ} \mathrm{C}\right.$.). All drugs were stopped, but the pyrexia persisted and the patient eventually died. Again this patient was receiving dipyridamole. There were no other episodes which might have been attributed to sensitivity to dipyridamole. The remaining four patients were excluded from the trial because adequate follow-up after their discharge from hospital was not possible.

Table I shows age, sex, and mortality rates for the 103 patients who completed the trial. The male patients show a reasonable correspondence in the numbers admitted to each age group, but the smaller numbers of female patients do not allows a similar match. The overall mortality for the 103 cases was $11(10.7 \%)$. The mortality for those receiving dipyridamole was $8(15.7 \%)$ and for the control group $3(5.8 \%)$. The causes of death are given in Table II.

TaBle I.-Age and Mortality Rate of Patients in Control and Treated

\begin{tabular}{|c|c|c|c|c|c|c|c|c|}
\hline \multirow{3}{*}{ Age } & \multicolumn{4}{|c|}{ Males } & \multicolumn{4}{|c|}{ Females } \\
\hline & \multicolumn{2}{|c|}{ Control } & \multicolumn{2}{|c|}{ Trial } & \multicolumn{2}{|c|}{ Control } & \multicolumn{2}{|c|}{ Trial } \\
\hline & No. & Deaths & No. & Deaths & No. & Deaths & No. & Deaths \\
\hline $\begin{array}{l}30-39 \\
40-49 \\
50-59 \\
60-69 \\
70-79 \\
80-89\end{array}$ & $\begin{array}{r}1 \\
8 \\
14 \\
14 \\
5 \\
1\end{array}$ & $\begin{array}{l}0 \\
0 \\
1 \\
0 \\
2 \\
0\end{array}$ & $\begin{array}{r}0 \\
8 \\
20 \\
15 \\
1 \\
0\end{array}$ & $\begin{array}{l}0 \\
0 \\
3 \\
3 \\
1 \\
0\end{array}$ & $\begin{array}{l}5 \\
1 \\
3\end{array}$ & $\begin{array}{l}0 \\
0 \\
0\end{array}$ & $\begin{array}{l}1 \\
4 \\
2\end{array}$ & $\begin{array}{l}0 \\
1 \\
0\end{array}$ \\
\hline Totals & 43 & 3 & 44 & 7 & 9 & 0 & 7 & 1 \\
\hline
\end{tabular}

TABLE II.-Causes of Death

\begin{tabular}{|c|c|c|c|c|c|}
\hline \multicolumn{4}{|c|}{ Cause of Death } & Control & Trial \\
\hline $\begin{array}{l}\text { Reinfarction } \\
\text { Cardiac failure } \ldots \\
\text { Ventricular fibrillation } \\
\text { Asystole } \quad . . \\
\text { Ventricular rupture } \\
\text { Pulmonary embolus }\end{array}$ & $\begin{array}{l}\ldots \\
\cdots \\
\ldots \\
\cdots\end{array}$ & $\begin{array}{l}\ldots \\
\because \\
\because \\
\therefore \\
\therefore\end{array}$ & $\begin{array}{l}\ldots \\
\cdots \\
\cdots \\
\cdots \\
\cdots\end{array}$ & $\begin{array}{l}2 \\
0 \\
0 \\
0 \\
1 \\
0\end{array}$ & $\begin{array}{l}1 \\
3 \\
1 \\
2 \\
0 \\
1\end{array}$ \\
\hline Total & . & . & . & 3 & 8 \\
\hline
\end{tabular}

Complications.-During the trial we were mainly interested in those incidents which might have been influenced by treatment with dipyridamole. These were episodes of new infarction, systemic and pulmonary emboli, and leg vein thrombosis. Six patients in the placebo group suffered complications $(11.5 \%)$. Two men had a new episode of infarction, and one woman had a further infarct and a leg vein thrombosis. One man suffered a deep venous thrombosis, and another had emboli into an arm and a leg. A man of 84 survived three extensions of an infarct and a leg vein thrombosis. In this group there were 11 complicating episodes in the six patients. Five men in the treatment group suffered complications $(9.8 \%)$. Two had a further infarct, one suffered a pulmonary embolus, another an embolus into the arm, and the fifth had emboli in the mesenteric, external iliac, and cerebral arteries. In the group receiving dipyridamole there were seven complicating episodes in five patients.

Time of Admission to Trial.-The intervals between the onset of myocardial infarction and admission to the trial are set out in Table III. Seventy-seven of the 103 patients $(74.8 \%$ ) were admitted to the trial within three days. Of this number, $36(46.7 \%)$ were in the control group and $41(53.2 \%)$ were in the treatment group. Table III also indicates that the higher

TABLE III.-Time of Admission to Trial

\begin{tabular}{|c|c|c|c|c|c|}
\hline \multirow{2}{*}{$\begin{array}{l}\text { Interval between } \\
\text { Infarct and } \\
\text { Admission (Days) }\end{array}$} & \multicolumn{2}{|c|}{ Control } & \multicolumn{3}{|c|}{ Trial } \\
\hline & No. & Deaths & No. & 1 & Deaths \\
\hline $\begin{array}{c}1 \\
2 \\
3 \\
7 \\
\text { Up to } 14 \\
\end{array}$ & $\begin{array}{r}14 \\
10 \\
12 \\
13 \\
3 \\
\end{array}$ & $\begin{array}{l}1 \\
1 \\
0 \\
1 \\
0\end{array}$ & $\begin{array}{r}16 \\
17 \\
8 \\
9 \\
1\end{array}$ & 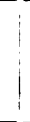 & $\begin{array}{l}2 \\
4 \\
1 \\
1 \\
0\end{array}$ \\
\hline Total & 52 & 3 & 51 & 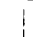 & 8 \\
\hline
\end{tabular}


mortality in the treatment group could be due in part to the larger number of patients admitted to this group in the first 48 hours.

Serum Dipyridamole Levels.-When possible blood for the estimation of serum dipyridamole was taken on the second and fifth days of treatment, and again on the 14th, 21st, and 28th days of the trial. The mean serum dipyridamole levels are set out in Table IV. As many patients left hospital before the end of the observation period the number of samples available for estimation declined progressively with time. The results obtained on those samples which were estimated show that the serum levels were well maintained. Moreover, the calculated means and their standard errors underestimated the true values, as levels of more than $10 \mu \mathrm{g} . / \mathrm{ml}$. were reported simply as $>10 \mu \mathrm{g} . / \mathrm{ml}$. The serum levels in the patients who died were calculated separately, and are set out in Table V. It can be seen that the serum dipyridamole levels achieved in these patients did not differ significantly from those in the treatment group as a whole.

TABLE IV.-Mean Serum Dipyridamole Levels ( \pm One Standard Error). Values Given in $\mu \mathrm{g} . / \mathrm{ml}$.

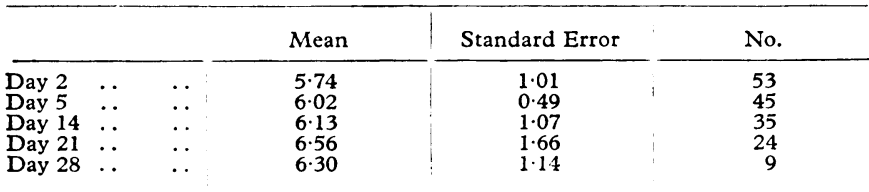

TABLE V.-Mean Serum Dipyridamole Levels in the Patients Who Died ( \pm One Standard Error). Values given in $\mu \mathrm{g} . / \mathrm{ml}$.

\begin{tabular}{lll|c|c|c}
\hline & & & Mean & Standard Error & No. \\
\hline Day 2 & $\ldots$ & $\cdots$ & 4.53 & 1.40 & 7 \\
Day 5 & $\cdots$ & $\cdots$ & 5.08 & 2.34 & 5 \\
Day 14 & $\cdots$ & $\cdots$ & 4.65 & - & 2 \\
Day 21 & $\cdots$ & $\cdots$ & 5.00 & & 1 \\
\hline
\end{tabular}

\section{Discussion}

It has been shown that adenosine and its analogues will cause both vasodilatation and inhibition of platelet clumping in the experimental animal (Born et al., 1964, 1965), though the brevity of its action would render it ineffective therapeutically. The short action of adenosine on the cardiovascular system has been attributed to its rapid deamination (Clarke et al., 1952), but its length of action was increased by dipyridamole, which in the presence of intact red cells effectively prevented the disappearance of adenosine (Bunag et al., 1964). Though dipyridamole inhibits adenosine deaminase its adenosine-sparing action is more likely to be due to a reduction in permeability of the red cell membrane to adenosine.

Emmons et al. (1965a) have shown that dipyridamole profoundly modifies thrombus formation in injured arteries in the rabbit and suggest that the drug acts at the site of injury rather than on the circulating blood. When added to human plasma in vitro, $50 \mu \mathrm{g} . / \mathrm{ml}$. inhibited the platelet aggregation induced by adenosine diphosphate (Emmons et al., 1965b), and when given to human subjects intravenously plasma levels of $3-5 \mu \mathrm{g} . / \mathrm{ml}$. would reduce the spontaneous clumping which occurs when platelet-rich plasma is stirred.

Though the drug was administered by mo'th, and there is some doubt about the efficiency of gastrointestinal absorption in the early stages of myocardial infarction, the results in Table IV show that effective levels were achieved and maintained throughout the period of treatment even in those patients who died (Table V). Moreover, intravenous administration would have been hazardous, as Born et al. (1965) have shown that intravenous adenosine can cause hypotension.
The effect which dipyridamole has on platelet function is paralleled by its action as a vasodilator. Dahl et al. (1962) showed that a dose of $0.2 \mathrm{mg}$. $/ \mathrm{kg}$. given intravenously to the cat would produce coronary artery vasodilatation lasting for 30 minutes. In experiments on dogs subjected to myocardial infarction the majority opinion (Asada et al., 1962 ; Vineberg et al., 1962 ; Rees and Redding, 1967) is that dipyridamole promotes survival and increases the anastomotic blood flow in the ischaemic area. Fam and McGregor (1964) agree that dipyridamole increases total coronary flow in dogs subjected to chronic myocardial ischaemia, but feel that no increase in collateral flow to the ischaemic area occurs.

Trials of the effects of treatment with dipyridamole have produced conflicting results. In a double-blind study Leiberman and Guglielmelli (1964) produced a statistically highly significant improvement in patients with arteriosclerotic cardiac failure, and improvement in angina, by giving dipyridamole $25 \mathrm{mg}$. q.d.s. However, Sbar and Schlant (1967), using a dose of $150 \mathrm{mg}$. daily, found, in a controlled trial, that dipyridamole did not benefit patients with angina. In other series without controls, Griep (1963) and Gaddy (1966) both stated that dipyridamole is a useful drug in the treatment of angina, while Newhouse and McGregor (1965) concluded that it is of little benefit in severe arteriosclerotic heart disease. We know of no previous attempt to assess the value of the drug in the treatment of acute myocardial infarction.

Our results have failed to show any benefit whatsoever from treatment with dipyridamole in patients with acute myocardial infarction. The overall mortality for patients in the trial $(10.7 \%)$ is lower than is usually reported, and we attribute this to the fact that patients were taken into the trial for up to 14 days after the initial myocardial infarct. In fact, $74.8 \%$ of all patients were admitted during the first three days. This low mortality may disguise a difference between the treated and control groups, but the lack of difference in our results suggests that this possibility is unlikely.

We would like to thank Professor W. I. Cranston for his help throughout the trial, and for his criticism of the manuscript; Dr. M. J. G. Harrison and Dr. J. R. Hampton, of the department of the Regius Professor of Medicine, Oxford, for their estimation of the serum dipyridamole levels; Miss Gillian Clemenson, of the E.C.G. Department ; and the Chief Pharmacist for his co-operation and assistance.

\section{REFERENCES}

Asada, S., Chiba, T., Osawa, K., Naganıura, K., and Murakawa, S. (1962). Fap. Circulat. F. (En.), 26, 849.

Born, G. V. R., Honour, A. J., and Mitchell, J. R. A. (1964). Nature (Lond.), 202, 761.

Born, G. V. R., Haslam, R. J., Goldman, M., and Lowe, R. D. (1965), Nature (Lond.), 205, 678 .

Bunag, R. D., Douglas, C. R., Imai, S., and Berne, R. M. (1964). Circulat. Res., 15, 83 .

Clarke, D. A., Davoll, J., Philips, F. S., and Brown, G. B. (1952). 7. Pharmacol. exp. Ther., 106, 291.

Dahl, M., Kasanen, A., and Peltonen, T. (1962). Ann. Med. exp. Fenn., 40, 423.

Emmons, P. R., Harrison, M. J. G., Honour, A. J., and Mitchell, J. R. A. (1965a). Nature (Lond.), 208, 255.

Emmons, P. R., Harrison, M. J. G., Honour, A. J., and Mitchell, J. R. A. (1965b). Lancet, 2, 603.

Fam, W. M., and McGregor, M. (1964). Circulat. Res., 15, 355.

Gaddy, C. G. (1966). Virg. med. Mth., 93, 336.

Griep, A. H. (1963). Angiology, 14, 484.

Leiberman, A., and Guglielmelli, S. (1964). Angiology, 15, 290.

Newhouse, M. T., and McGregor, M. (1965). Amer. F. Cardiol, 16, 234.

Rees, J. R., and Redding, V. J. (1967). Cardiovasc. Res., 1, 179.

Sbar, S., and Schlant, R. C. (1967). F. Amer. med. Ass., 201, 865.

Vineberg, A. M., Chari, R. S., Pifarre, R., and Mercier, C. (1962). Un. méd. Can., $91,1068$. 